\title{
Improvement of Microstomia in Scleroderma after Carbon Dioxide Laser Treatment
}

\author{
Imane Bennani $^{a} \quad$ Raphael Lopez $^{b} \quad$ Delphine Bonnet $^{c} \quad$ Gregoire Prevot $^{d}$ \\ Arnaud Constantin $^{e}$ Dominique Chauveau ${ }^{f}$ Carle Paul $^{a}$ \\ Cristina BulaiLivideanu ${ }^{a}$ \\ ${ }^{\mathrm{a}}$ Department of Dermatology, Paul Sabatier University, and Departments of ${ }^{\mathrm{b}}$ Oral and \\ Maxillofacial Surgery, ${ }^{\mathrm{C}}$ Internal Medicine, ${ }^{\mathrm{d}}$ Pulmonology, ${ }^{\mathrm{e}}$ Rheumatology and ${ }^{\mathrm{f}}$ Nephrology, \\ Toulouse University Hospital, Toulouse, France
}

\section{Key Words}

Systemic sclerosis · Microstomia - Limited mouth opening · Carbon dioxide laser · Interincisal distance $\cdot$ Mouth Handicap in Systemic Sclerosis scale

\begin{abstract}
Limited mouth opening (LMO) is a frequent complication of systemic sclerosis (SS). Its management is complex and there are limited treatment options. We report four patients with SS and severe $\mathrm{LMO}$ [interincisal distance (IID) $<30 \mathrm{~mm}$ ] treated with pulsed carbon dioxide $\left(\mathrm{CO}_{2}\right)$ laser. Pulsed $\mathrm{CO}_{2}$ laser treatment of the white lips was performed after all patients had signed a written informed consent in the absence of alternative treatment. Treatment was carried out under locoregional anaesthesia using a Sharplan $30 \mathrm{C} \mathrm{CO}_{2}$ laser in the Silk Touch ${ }^{\circledR}$ resurfacing mode. One to three laser sessions were performed at intervals of 8-12 months between sessions. Assessments were performed at 3 and 12 months with measurement of the IID using a ruler, calculation of the Mouth Handicap in Systemic Sclerosis (MHISS) scale and global evaluation by the patients. Adverse events were also reported. In all four patients, an improvement in IID occurred 3 months after the first session with a mean gain of $+5 \mathrm{~mm}$ (range: 2-7). At 12 months, a mean gain of $+8.5 \mathrm{~mm}$ (range: 7-10) in IID was observed. The MHISS score decreased by a mean of -14 (range: 11-17). All patients showed improvement of lip flexibility or mouth opening, allowing better phonation and mastication and easier dental care. Adverse effects were transient erythema and/or dyschromia. $\mathrm{CO}_{2}$ laser appears to be effective and well tolerated in the improvement of LMO in SS.
\end{abstract}

\section{KARGER}

Cristina Bulai Livideanu

Department of Dermatology, Toulouse University Hospital

24, Chemin de Pouvourville TSA 30030

FR-31059 Toulouse Cedex 9 (France)

E-Mail livideanu.c@chu-toulouse.fr 


\section{Case Reports in Dermatology}

Bennani et al: Improvement of Microstomia in Scleroderma after Carbon Dioxide Laser Treatment

\section{Introduction}

Systemic sclerosis (SS) is associated with functional consequences that significantly impact on patients' quality of life [1]. Progressive facial dermal fibrosis is responsible for limited mouth opening (LMO), which interferes with mastication and phonation. Basic oral hygiene care can become impossible [2]. Severe LMO is defined by an interincisal distance (IID) $<30 \mathrm{~mm}$ [3]. The management of LMO is complex and there are limited treatment options available. We report four patients with SS associated with severe LMO who were treated with pulsed carbon dioxide $\left(\mathrm{CO}_{2}\right)$ laser.

\section{Materials and Methods}

\section{Patients}

Between January 2012 and November 2014, four SS patients with severe LMO refractory to conventional physical therapy received pulsed $\mathrm{CO}_{2}$ laser treatment of the white lips. The laser treatment was performed by C.B.L. All patients signed a written informed consent. This treatment is substantiated by the publication of Apfelberg et al. [4], who recommended $\mathrm{CO}_{2}$ laser treatment of perioral rhytids in SS, and is effective in improving skin appearance without severe complications.

\section{$\mathrm{CO}_{2}$ Laser Procedure}

Prophylaxis of infectious complications associated with $\mathrm{CO}_{2}$ laser was performed by the application of topical $2 \%$ sodium fusidate ointment (Fucidin ${ }^{\circledR}$ ) twice a day into the nostrils, starting 5 days before the procedure and continuing until complete healing, and oral administration of valacyclovir (Zelitrex ${ }^{\circledR}$ ) $500 \mathrm{mg}$ daily, starting 2 days before the procedure and continuing until complete healing $[5,6]$.

$\mathrm{CO}_{2}$ laser treatment was carried out under locoregional anaesthesia using $1 \%$ lidocaine solution containing $0.005 \mathrm{mg} / \mathrm{ml}$ adrenaline (Xylocaine adrenaline ${ }^{\circledR} 1 \%$ ). Anaesthesia of the lips was obtained by infiltrating the infraorbital and mental nerves. If required, lidocaine solution was additionally infiltrated directly into the lip tissue. Saline-soaked gauze was placed in the mouth between the teeth and lips to prevent accidental teeth burns. The Sharplan 30C $\mathrm{CO}_{2}$ laser (Sharplan Lasers, Lumenis SARL, Suresnes, France) used the Silk Touch ${ }^{\circledR}$ resurfacing mode with a $125-\mathrm{mm}$ handpiece, $5 \mathrm{~mm}$ spot, $7 \mathrm{~W}, 0.39 \mathrm{~ms}$. We performed 2-3 passes until contraction of the dermis was obtained. Each pass was carried out without overlapping the spots on the white lips, maintaining a distance of $2 \mathrm{~mm}$ from the commissures and the red lips. We did not remove the epidermis between each pass so as to prevent heat diffusion and reduce the risk of scarring (fig. 1) [7]. At the end of the treatment, equal quantities of $2 \%$ sodium fusidate ointment and sterile Vaseline ${ }^{\circledR}$ were applied three times daily to the white lips without dressing [6]. Paracetamol $1 \mathrm{~g}$ three times a day was used on an as-needed basis for pain. All patients were instructed to clean the treated white lips with sterile physiological saline solution and to continue application of sodium fusidate ointment and sterile Vaseline ${ }^{\circledR}$ mixture three times daily until complete healing (on average 12 days) to help healing and reduce the risk of infection [6]. The numbers of sessions (1-3) and the interval between two sessions (8-12 months) varied according to the patient's and physician's perception of clinical effectiveness. 


\section{Case Reports in Dermatology}

\begin{tabular}{l|l}
\hline Case Rep Dermatol 2016;8:142-150 \\
\hline DOI: 10.1159/000445821 & $\begin{array}{l}\text { ○ } 2016 \text { The Author(s). Published by S. Karger AG, Basel } \\
\text { www.karger.com/cde }\end{array}$
\end{tabular}

Bennani et al.: Improvement of Microstomia in Scleroderma after Carbon Dioxide Laser Treatment

\section{Clinical Evaluation of Treatment}

Patients were evaluated 3 and 12 months after each session by I.B. or C.P. Physician assessment was based on measurements of IID at each visit. The measurement of IID was standardised. Maximum IID was measured using a small ruler, as the distance in mm between the upper and lower incisal edges of the right central incisors. The participants were requested to open their mouth as wide as possible [8]. Patient assessment was based on the Mouth Handicap in Systemic Sclerosis (MHISS) scale (0-48) [9], and a global clinical assessment using a three-point ordinal scale $(+1=$ improvement; $0=$ no change; $-1=$ worsening) and to evaluate the response to the question: 'What is improved by this treatment?' In addition, pre- and posttreatment photographs were performed. Adverse events were reported at each visit.

\section{Results}

\section{Patient Characteristics}

Four nonsmoking female SS patients received laser treatment. The phototype varied from II to IV and the mean age was 52 years (range: 43-63). Two patients were diagnosed with diffuse SS with antitopoisomerase antibodies; one had scleromyositis with anti-PM/SCL antibodies and the other had CREST (calcinosis, Raynaud phenomenon, esophageal involvement, sclerodactyly and telangiectases) syndrome with anticentromere antibodies. Skin sclerosis had been present for at least 5 years in all patients. The mean modified Rodnan skin score was 15.5/51 (range: $12-18$ ) and remained stable during the follow-up period. No patient received immunosuppressive therapy during or in the 12 months prior to laser treatment. No patient underwent physical therapy or practised stretching exercises to improve mouth opening during the follow-up period or in the 12 months prior to treatment. The initial mean IID and MHISS scores were $24.25 \mathrm{~mm}$ (range: 17-30) and 39 (range: 3144), respectively.

\section{Clinical Evaluation of Treatment}

In all patients, an improvement in IID was observed 3 months following the first $\mathrm{CO}_{2}$ laser session with a mean gain of $+5 \mathrm{~mm}$ (range: 2-7). In patients receiving a second laser session $(n=3)$, an additional mean gain of $+1.66 \mathrm{~mm}$ (range: $1-3$ ) in IID was observed 3 months after the second session. At 12 months, the mean gain in IID was $+8.5 \mathrm{~mm}$ (range: $7-$ 10), corresponding to an improvement in IID of about $37.37 \%$ (range: 24.1-58.8) (fig. 2, fig. 3). The MHISS score was evaluated in three patients and improved by a mean of -14 (range: 11-17). All patients assessed the response to therapy as $+1=$ improvement. All patients showed an improvement in lip flexibility and/or mouth opening with better phonation and mastication and/or easier dental care. Demographic, clinical and therapeutic data are summarised in table 1.

\section{Discussion}

$\mathrm{CO}_{2}$ laser treatment of severe LMO in SS patients was associated with significant improvement in mouth opening 3 months after the first laser session (mean $+5 \mathrm{~mm}$ vs. baseline) with further improvement observed at 12 months (mean $+8.5 \mathrm{~mm}$ vs. baseline). This improvement was clinically relevant and resulted in a reduction of mouth handicap as evaluated by the MHISS score. 
Bennani et al.: Improvement of Microstomia in Scleroderma after Carbon Dioxide Laser Treatment

The mechanism by which abrasive laser improves fibrosis in SS is not known. By analogy to what has been shown in the treatment of photoaging or scars, several hypotheses can be advanced. $\mathrm{CO}_{2}$ laser could modulate the expression of transforming growth factor beta 1 [10], a major profibrotic mediator [11], resulting in normalisation of collagen balance. The abnormal increase in expression of collagen 1 in SS [12] may be modulated during $\mathrm{CO}_{2}$ laser treatment [13] and a more homogeneous architecture of the dermis could be restored. $\mathrm{CO}_{2}$ laser may also modulate the expression of VEGF, which is involved in the early stage of neocollagenesis [14].

Treatment of LMO in SS is not standardised and there are limited treatment options. In 2011, an expert group proposed recommendations for the management of oral complications in SS [3]. The recommended treatment for LMO is based on stretching exercises for 3 months [3]. Pizzo et al. [15] reported a mean gain of $+10.7 \mathrm{~mm}$ in IID after 18 months of stretching exercises. Another study reported a mean improvement of $+5.7 \mathrm{~mm}$ of IID after 3 months of exercises [16]. There is limited standardisation of stretching exercises in terms of nature, frequency and duration. A minimum duration of 15 min twice a day is required [15]. They also need to be continued in the long term if the benefit is to be maintained [17]. Combination treatments including physiotherapy, massage and physical therapy may also improve mouth opening. The main limitation of these treatments is the lack of trained physical therapists. There are no data on the efficacy of $\mathrm{CO}_{2}$ laser for the treatment of $\mathrm{LMO} . \mathrm{CO}_{2}$ laser treatment was evaluated in the management of perioral rhytids in patients with SS without any assessment of mouth opening [4] and was recommended by the expert group only for the treatment of perioral wrinkles [3]. Intense pulsed light treatment and perioral autologous fat injections have been advocated for the treatment of LMO. However, the reported efficacy was limited $[18,19]$.

The main limitations of our work are: the small number of patients treated. Better objective methods to assess clinical response for oral aperture in this condition in a multicentre setting are needed. Also, we understand the limitations in our work of the photographs which were performed without ruler. However, the evaluation of results has also included the MHISS scale, a validated scale in SS, and taken into account the patient perception. This confirms the clinical relevance of our findings. In addition, we did not assess intraoral sclerosis specifically.

In conclusion, $\mathrm{CO}_{2}$ laser treatment of the white lips in $\mathrm{SS}$ seems to be an effective treatment of LMO. It is associated with improved mouth opening and patient quality of life.

\section{Acknowledgment}

Thanks to Ms Marielle Romet and her team for English review of the manuscript.

\section{Statement of Ethics}

This article reports on a treatment procedure that is part of usual care for patients with skin diseases. It does not qualify as a study requiring ethical approval by an IRB in France. All patients signed a written informed consent for laser treatment. 


\section{Case Reports in Dermatology}

Bennani et al.: Improvement of Microstomia in Scleroderma after Carbon Dioxide Laser Treatment

\section{Disclosure Statement}

The authors have no conflicts of interest to disclose. There was no funding for this work.

\section{References}

1 Amin K, Clarke A, Sivakumar B, et al: The psychological impact of facial changes in scleroderma. Psychol Health Med 2011;16:304-312.

2 Albilia JB, Lam DK, Blanas N, et al: Small mouths. Big problems? A review of scleroderma and its oral health implications. J Can Dent Assoc 2007;73:831-836.

-3 Alantar A, Cabane J, Hachulla E, et al: Recommendations for the care of oral involvement in patients with systemic sclerosis. Arthritis Care Res 2011;63:1126-1133.

-4 Apfelberg DB, Varga J, Greenbaum SS: Carbon dioxide laser resurfacing of peri-oral rhytids in scleroderma patients. Dermatol Surg Off Publ Am Soc Dermatol Surg Al 1998;24:517-519.

5 Naouri M, Delage M, Khallouf R, Georgesco G, Atlan M: $\mathrm{CO}_{2}$ fractional resurfacing: side effects and immediate complications. Ann Dermatol Venereol 2011;138:7-10.

-6 Sriprachya-Anunt S, Fitzpatrick RE, Goldman MP, Smith SR: Infections complicating pulsed carbon dioxide laser resurfacing for photoaged facial skin. Dermatol Surg 1997;23:527-535.

7 Niamtu J: To debride or not to debride? That is the question: rethinking char removal in ablative $\mathrm{CO}_{2}$ laser skin resurfacing. Dermatol Surg 2008;34:1200-1211.

-8 Yuen HK, Marlow NM, Reed SG, et al: Effect of orofacial exercises on oral aperture in adults with systemic sclerosis. Disabil Rehabil 2012;34:84-89.

-9 Mouthon L, Rannou F, Bérezné A, et al: Development and validation of a scale for mouth handicap in systemic sclerosis: the Mouth Handicap in Systemic Sclerosis scale. Ann Rheum Dis 2007;66:1651-1655.

10 Jiang $\mathrm{X}, \mathrm{Ge} \mathrm{H}$, Zhou C, et al: The role of transforming growth factor $\beta 1$ in fractional laser resurfacing with a carbon dioxide laser. Lasers Med Sci 2014;29:681-687.

11 Chen Y, Shi-Wen X, van Beek J, et al: Matrix contraction by dermal fibroblasts requires transforming growth factor-beta/activin-linked kinase 5, heparan sulfate-containing proteoglycans, and MEK/ERK: insights into pathological scarring in chronic fibrotic disease. Am J Pathol 2005;167:1699-1711.

-12 Ponticos M, Papaioannou I, Xu S, et al: Failed degradation of JunB contributes to overproduction of type I collagen and development of dermal fibrosis in patients with systemic sclerosis. Arthritis Rheumatol 2015;67:243-253.

13 Ozog DM, Liu A, Chaffins ML, et al: Evaluation of clinical results, histological architecture, and collagen expression following treatment of mature burn scars with a fractional carbon dioxide laser. JAMA Dermatol 2013;149:50-57.

14 Jiang X, Ge H, Zhou C, et al: The role of vascular endothelial growth factor in fractional laser resurfacing with the carbon dioxide laser. Lasers Med Sci 2012;27:599-606.

15 Pizzo G, Scardina GA, Messina P: Effects of a nonsurgical exercise program on the decreased mouth opening in patients with systemic scleroderma. Clin Oral Investig 2003;7:175-178.

16 Naylor WP, Douglass CW, Mix E: The nonsurgical treatment of microstomia in scleroderma: a pilot study. Oral Surg Oral Med Oral Pathol 1984;57:508-511.

17 Maddali Bongi S, Del Rosso A, Galluccio F, et al: Efficacy of a tailored rehabilitation program for systemic sclerosis. Clin Exp Rheumatol 2009;27:44-50.

18 Comstedt LR, Svensson A, Troilius A: Improvement of microstomia in scleroderma after intense pulsed light: a case series of four patients. J Cosmet Laser Ther Off Publ Eur Soc Laser Dermatol 2012;14:102-106.

19 Del Papa N, Caviggioli F, Sambataro D, et al: Autologous fat grafting in the treatment of fibrotic perioral changes in patients with systemic sclerosis. Cell Transplant 2013, Doi: 10.3727/096368913X674062. 


\section{Case Reports in Dermatology}

\begin{tabular}{l|l}
\hline Case Rep Dermatol 2016;8:142-150 \\
\hline DOI: $10.1159 / 000445821$ & $\begin{array}{l}\text { C } 2016 \text { The Author(s). Published by S. Karger AG, Basel } \\
\text { www.karger.com/cde }\end{array}$ \\
\hline
\end{tabular}

Bennani et al.: Improvement of Microstomia in Scleroderma after Carbon Dioxide Laser Treatment

Table 1. Demographic, clinical and therapeutic characteristics of patients

\begin{tabular}{|c|c|c|c|c|}
\hline Patient characteristic & Patient 1 & Patient 2 & Patient 3 & Patient 4 \\
\hline Sex & female & female & female & female \\
\hline Age, years & 57 & 63 & 43 & 45 \\
\hline Phototype & 4 & 2 & 3 & 2 \\
\hline Type of SS & dSS & CREST syndrome & dSS & scleromyositis \\
\hline Year of diagnosis & 2007 & 1990 & 2008 & 1996 \\
\hline $\begin{array}{l}\text { Modified Rodnan score } \\
(0-51)\end{array}$ & 17 & 18 & 12 & 15 \\
\hline $\begin{array}{l}\text { Concurrent systemic } \\
\text { disease }\end{array}$ & none & high blood pressure & none & none \\
\hline Concurrent medications & $\begin{array}{l}\text { nifedipine extended- } \\
\text { release } 30 \mathrm{mg} / \text { day }\end{array}$ & $\begin{array}{l}\text { omeprazole } 20 \mathrm{mg} / \text { day, } \\
\text { alendronate } 70 \mathrm{mg} / \text { month, } \\
\text { irbesartan/hydrochloro- } \\
\text { thiazide } 150 / 12.5 \mathrm{mg} / \text { day, } \\
\text { amlodipine } 5 \mathrm{mg} / \text { day }\end{array}$ & $\begin{array}{l}\text { nicardipine } 20 \mathrm{mg} / \text { day, } \\
\text { hydroxy-chloroquine } 200 \mathrm{mg} / \text { day, } \\
\text { bosentan } 125 \mathrm{mg} \times 2 / \text { day, } \\
6 \text { months/year } \\
\text { iloprost infusion } 0.5-1 \mathrm{ng} / \mathrm{kg} / \mathrm{min}(6 \mathrm{~h} \\
\text { per day, for } 5 \text { days every } 6-8 \text { weeks), } \\
6 \text { months/year }\end{array}$ & $\begin{array}{l}\text { diltiazem } 60 \mathrm{mg} \times \\
\text { 2/day }\end{array}$ \\
\hline $\begin{array}{l}\text { Dates of } \mathrm{CO}_{2} \text { laser ses- } \\
\text { sions }\end{array}$ & $\begin{array}{l}\text { S1: } 01 / 2012 \\
\text { S2: } 11 / 2012 \\
\text { S3: } 11 / 2013\end{array}$ & $\begin{array}{l}\text { S1: } 04 / 2013 \\
\text { S2: } 12 / 2013\end{array}$ & S1: $01 / 2014$ & $\begin{array}{l}\text { S1: } 01 / 2014 \\
\text { S2: } 11 / 2014\end{array}$ \\
\hline IID, mm & $\begin{array}{l}\text { initial: } 29 \\
\text { S1, M3: } 34 \\
\text { S2, M3: } 35 \\
\text { S3, M3: ND } \\
\text { S3, M12: } 36 \\
\text { final gain: }+7 \\
(24.1 \%)\end{array}$ & $\begin{array}{l}\text { Initial: } 17 \\
\text { S1, M3: } 24 \\
\text { S2, M3: } 25 \\
\text { S2, M12: } 27 \\
\text { final gain: }+10 \\
(58.8 \%)\end{array}$ & $\begin{array}{l}\text { initial: } 26 \\
\text { S1, M3: } 32 \\
\text { S1, M12: } 35\end{array}$ & $\begin{array}{l}\text { initial: } 25 \\
\text { S1, M3: } 27 \\
\text { S2, M3: } 30 \\
\text { S2, M12: } 33 \\
\text { final gain: +8 } \\
(32 \%)\end{array}$ \\
\hline$\overline{\text { MHISS (0-48) }}$ & ND & $\begin{array}{l}\text { initial: } 44 \\
\text { final: } 30\end{array}$ & $\begin{array}{l}\text { initial: } 31 \\
\text { final: } 14\end{array}$ & $\begin{array}{l}\text { initial: } 42 \\
\text { final: } 31\end{array}$ \\
\hline $\begin{array}{l}\text { Patient global assessment } \\
\text { of treatment response } \\
(-1,0,+1)\end{array}$ & +1 & +1 & +1 & +1 \\
\hline $\begin{array}{l}\text { Open question to pa- } \\
\text { tients: 'What is improved } \\
\text { by this treatment?' }\end{array}$ & $\begin{array}{l}\text { lip flexibility and easier } \\
\text { dental care }\end{array}$ & $\begin{array}{l}\text { lip flexibility and mouth open- } \\
\text { ing with better phonation and } \\
\text { mastication and easier dental } \\
\text { care }\end{array}$ & $\begin{array}{l}\text { mouth opening with better mastication } \\
\text { and easier dental care }\end{array}$ & $\begin{array}{l}\text { lip flexibility with } \\
\text { better phonation and } \\
\text { mastication and easier } \\
\text { dental care }\end{array}$ \\
\hline $\begin{array}{l}\text { Adverse events (duration } \\
\text { in days) }\end{array}$ & $\begin{array}{l}\text { erythema: } 15 \\
\text { pigmentation: } 90\end{array}$ & $\begin{array}{l}\text { erythema: } 15 \\
\text { pigmentation: } 90\end{array}$ & $\begin{array}{l}\text { erythema: } 15 \\
\text { hypochromia: } 90\end{array}$ & erythema: 15 \\
\hline
\end{tabular}

dSS = Diffuse systemic scleroderma; $\mathrm{S}=$ session; $\mathrm{M}=$ month; $\mathrm{ND}=$ not done. 
Case Reports in
Dermatology

Case Rep Dermatol 2016;8:142-150

\begin{tabular}{l|l}
\hline DOI: $10.1159 / 000445821$ & C 2016 The Author(s). Published by S. Karger AG, Basel
\end{tabular} www.karger.com/cde

Bennani et al.: Improvement of Microstomia in Scleroderma after Carbon Dioxide Laser Treatment
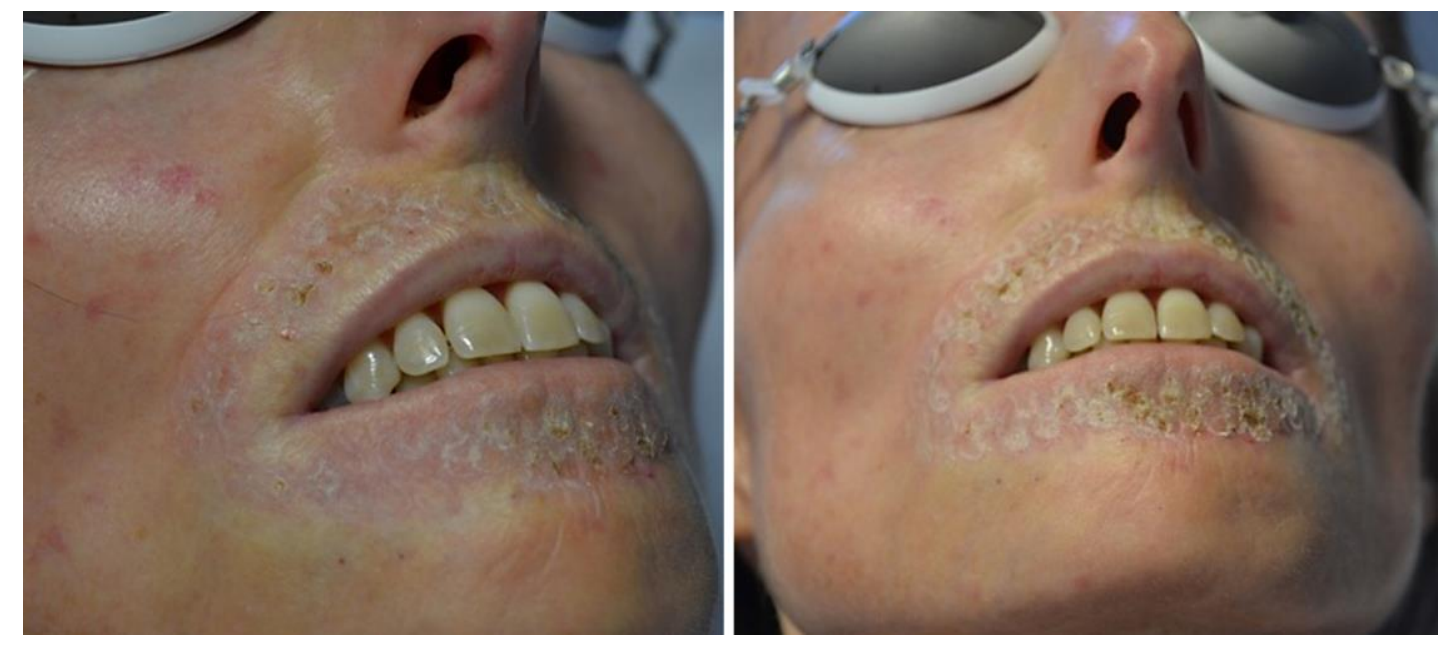

Fig. 1. Immediate appearance after pulsed $\mathrm{CO}_{2}$ laser treatment in patient 4 . 


\section{Case Reports in Dermatology}

Bennani et al: Improvement of Microstomia in Scleroderma after Carbon Dioxide Laser Treatment
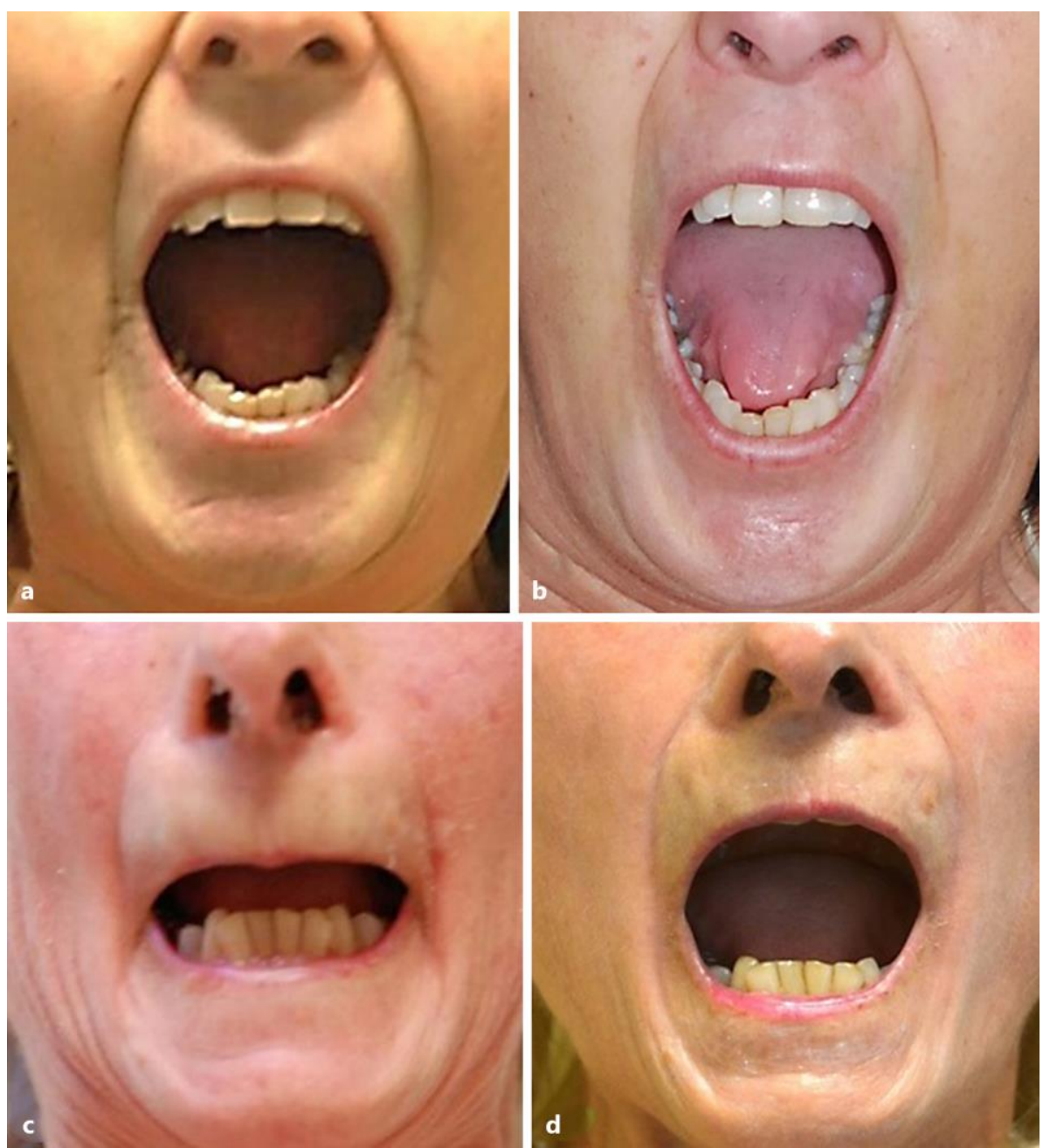

Fig. 2. First and second patients. a Mouth opening before $\mathrm{CO}_{2}$ laser treatment in the first patient. $\mathbf{b}$ Mouth opening after the last evaluation in the first patient. c Mouth opening before $\mathrm{CO}_{2}$ laser treatment in the second patient. $\mathbf{d}$ Mouth opening after the last evaluation in the second patient. 


\section{Case Reports in Dermatology}

Bennani et al: Improvement of Microstomia in Scleroderma after Carbon Dioxide Laser Treatment
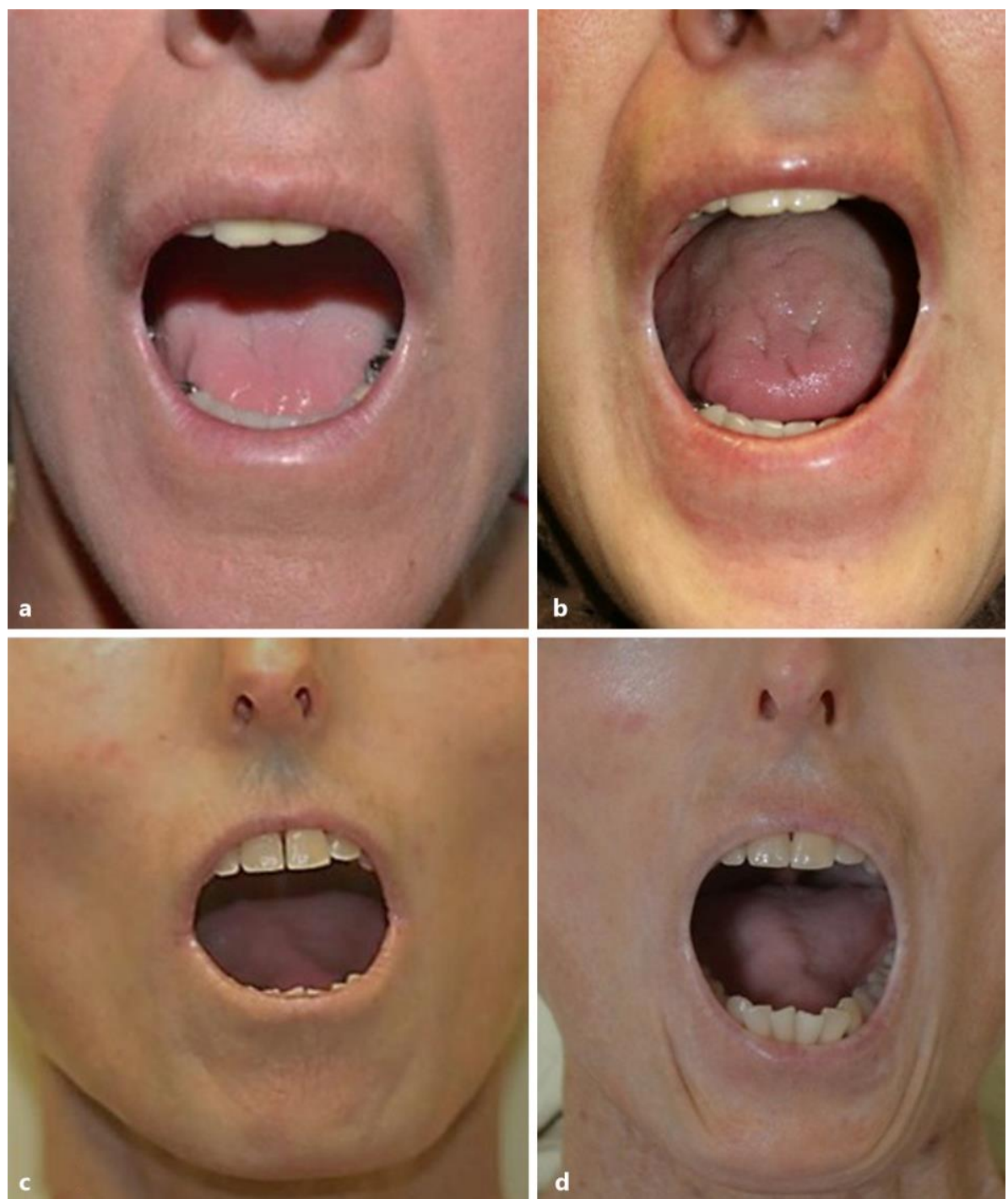

Fig. 3. Third and fourth patients. a Mouth opening before $\mathrm{CO}_{2}$ laser treatment in the third patient. b Mouth opening after the last evaluation in the third patient. c Mouth opening before $\mathrm{CO}_{2}$ laser treatment in the fourth patient. $\mathbf{d}$ Mouth opening after the last evaluation in the fourth patient. 